\title{
Attitudes Of Chinese Listed Enterprises Toward Cash Flow Manipulation: A Resource Dependence Perspective
}

Huiting Guo, Chang'an University, China

Fangjun Wang, Xi'an Jiaotong University, China

Junrui Zhang, Xi'an Jiaotong University, China

\begin{abstract}
The prevalence of cash flow manipulation has drawn much scholarly attention in China and worldwide, especially since the exposure of the accounting scandals at Enron, WorldCom, and Qwest. Cash flow status also provides a sound basis for corporate valuation. Using a sample of 12,251 firm-year observations from 1999 to 2009, this study thus investigates the attitudes and behavioral patterns of state-owned enterprises (SOEs) and non-SOEs in China toward cash flow manipulation. From a point of departure of resource-dependence theory, we find that non-SOEs tend to manipulate cash flow upward, whereas SOEs are more prone to manipulate cash flow downward. We also demonstrate that non-SOEs are more inclined to manipulate their cash flow statements compared with SOEs. The reason behind this differing behavior could be that nonSOEs are reliant on cash and funds from entities, such as governments and banks, and thus, they falsely enhance cash flow and firm performance in order to signal their solvency and thereby reduce financing costs. By contrast, since SOEs always receive sufficient cash inflows from both government sources and state-owned banks, the managers of these firms are unconcerned about cash flow shortages, which lessens their motivation to manipulate the figures. Indeed, this study finds that these managers may even reduce reported cash flow intentionally in order to obtain government assistance. Therefore, investors and regulators should make their judgments on the cash flow of entities based on their status as SOEs or non-SOEs.
\end{abstract}

Keywords: Cash Flow Manipulation; State-Owned Enterprise; Non-State-Owned Enterprise; Resource Dependence Theory

\section{INTRODUCTION}

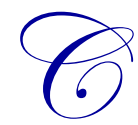

ash flow is recognized as the lifeblood of a firm. All companies rely on sufficient cash flow to invest in new projects, repay debt, pay dividends to shareholders, and provide a safety net for emergencies (Dittmar, Mahrt-Smith, \& Servaes, 2003). Cash flow status thus provides a sound basis for corporate valuation. The importance of operating cash flow has been repeatedly emphasized over recent decades, especially its role in appraising CEO performance and agreeing compensation packages (Aboody \& Kasznik, 2000; Nwaeze, Yang, \& Yin, 2006). Operating cash flow can also improve the accuracy of investor forecasting (Hewitt, 2009; Waldron \& Jordan, 2010). In particular, demand for detailed current year and forecasted cash flow information has increased since the exposure of the accounting scandals at Enron, WorldCom, and Qwest revealed that these organizations were engaged in obvious cash flow manipulations (Edmonds, Edmonds, \& Maher, 2011).

Cash flow manipulation is defined as the managerial tendency to use internal resources to change reported cash flow in order to achieve predetermined goals (Zhang, Dong, \& Guo, 2007). For example, managers could increase cash inflow at year end by collecting greater amounts of accounts receivable (e.g., by offering aggressive discounts to clients) or by delaying payments to suppliers. However, managers cannot use financing activities to manipulate a firm's cash flow because these are mainly constrained by creditors. On the contrary, financing activities are always the result of cash flow manipulation. Cash flow manipulation has recently been documented in 
Western developed security markets (Frankel, 2005) while the prevalence of cash flow manipulation has also drawn much scholarly attention in China (Wang, 2004a, 2004b; Fang, 2005; Chen, 2006; Zhang, 2007; Guo, Zhang, \& Dong, 2007; Zhang, Guo, \& Wang, 2008; Zhang, Guo, \& Xu, 2010; Guo, Zhang, \& Li, 2011).

Because more than $70 \%$ of Chinese-listed companies are state-owned, the present paper contributes to the extant cash flow manipulation literature by shedding light on the differences between state-owned enterprises $(\mathrm{SOEs})^{1}$ and non-state-owned enterprises (non-SOEs); namely, companies controlled by families, institutional investors, and other non-SOEs. Further, because SOEs have strong political backgrounds and expect financial support from the government, they have many varied resources, which are more adequate (including cash flow), compared with non-SOEs. Further, compared with SOEs, non-SOEs have more difficulty accessing credit from banks and government grants. Therefore, there are significant differences in the supply and demand of cash flow between SOEs and non-SOEs. This raises the following important questions: 1) What are the different motivations behind cash flow manipulation in SOEs and in non-SOEs and 2) Do SOEs and non-SOEs manipulate reported cash flows to a similar degree?

This paper answers these two research questions by comparing the cash flow manipulation behavior of SOEs and non-SOEs listed on the Chinese stock market. From the empirical results, we find that the degree of cash flow manipulation is more serious in non-SOEs than it is in SOEs. An interesting observation is that non-SOEs are more prone to increase reported cash flows, while SOEs tend to decrease reported cash flows.

\section{LITERATURE REVIEW AND HYPOTHESES DEVELOPMENT}

\section{Cash Flow Manipulation}

Cash flow data provide important information for the assessment of a company's value. Although earnings are considered to be an important measure of firm performance, they can prove to be less reliable (Dechow, 1994). Earnings are produced under accrual accounting, but the method of accruals introduces its own problems, as it gives managers opportunities to use their discretion to manipulate the figures. Cash flow statements, on the contrary, are more difficult to manipulate. Thus, cash flow information is viewed as more solid evidence and less susceptible to artificial manipulation compared with actual reported accounting earnings (Edmonds et al., 2011).

Operating cash flow is playing an increasingly significant role in improving the accuracy of investors' firm forecasts (Hewitt, 2009). Sufficient cash flow also provides evidence of a company's capability to repay its loans (Dichev \& Skinner, 2002). Hence, cash flow is the most efficient method for reflecting solvency. As a result, more and more companies are intentionally increasing their degree of reporting on cash flow. However, increasing demand for detailed cash flow information and cash flow forecasts has resulted in accounting scandals involving cash flow manipulation (Edmonds et al., 2011).

In addition to the global accounting scandals involving Enron and WorldCom, a number of studies have also shown the existence of cash flow manipulation practices in China's emerging stock market. Fang (2005) and Wang (2004a) first proposed the existence of cash flow manipulation in Chinese listed companies. Chen (2006) and Zhang et al. (2008) then found that Chinese listed companies manipulate their cash flow statements, especially during periods of refinancing. Evidence of cash flow manipulation was also found in management buy-outs (Guo et al., 2007). Zhang (2007) further extended the research on this topic by using the concept of earnings thresholds to compare cash flow manipulation in China's emerging market with the mature market in the US. The author proved that managers manipulate cash flow in order to beat three thresholds: current cash flow, the previous year's cash flow, and analysts' cash flow forecasts. Zhang et al. (2010) and Guo et al. (2011) also found a hierarchy of these three thresholds of cash flow manipulation in China.

\footnotetext{
${ }^{1}$ State-owned enterprises (SOEs) are companies that are under the control of state. There are four main types of ownership in Chinese-listed companies - State ownership, legal-person ownership held by State-owned firms or institutions, private ownership, and foreign ownership. 


\section{Background of SOEs and Non-SOEs}

Previous studies that have focused on mature markets such as the US or the UK have examined whether (i) accruals add information to operating cash flow in order to improve earnings ability and thus explain profit returns and (ii) discretionary and nondiscretionary accruals are priced differently (Haw, Qi, \& Wu, 2001). However, the role of operating cash flow has yet to be studied in the emerging capital market of China. Although the Ministry of Finance in China has issued new accounting standards, these standards and practices in China are still evolving. Moreover, the financial reporting and capital market systems are still considered to be relatively primitive and the quality of auditing is low compared with the mature markets in the west, whose accounting systems are more sophisticated and investors relatively well informed (Abdel-Khalik, Wong, \& Wu, 1999; Aharony, Lee, \& Wong, 2000). In addition, some critics argue that accounting information in emerging capital markets such as China may not be reliable or even useful to investors, especially since choices of accounting methods and management decisions are affected by a company's status as an SOE or non-SOE. Thus, the closer examination of the supply and demand of cash flow information could help us understand the problem of cash flow manipulation in China's emerging capital market.

A salient institutional feature is that state ownership dominates listed companies in China (Sun \& Tong, 2003). Most Chinese listed firms are carve-outs or spin-offs from large SOEs, in which the original firms still own a large percentage of the total shares (Liu \& Lu, 2007). Consequently, state ownership accounted for approximately $70 \%$ of total businesses in 2006 (Zou and Xiao, 2006). This distinct feature is a result of China's "gradualist" reform strategy as opposed to the "big bang" privatization approach taken by certain eastern European countries (Qian, Roland, \& Xu, 1999). Since its reforms and open door policy, China has made great economic progress, with SOEs and non-SOEs playing an essential role in these economic reforms. With the gradual deepening of enterprise reform, corporate performance has become the most important criterion for evaluating firm value and managerial capability. As such, cash flow provides crucial information for assessing company value, and managers in SOEs and non-SOEs are all paying more attention to cash flow than ever before.

\section{Resource Dependence Theory and Hypotheses Development}

Resource dependence theory suggests that no group is self-sufficient and that social relations commonly entail mutual dependence between parties. These mutual needs imply that each party is in a position, at least to some degree, to be able to grant or deny, facilitate or hinder the other's gratification. This means that A depends on B if A aspires to goals or gratification whose achievement is facilitated by the appropriate actions on B's part. By virtue of mutual dependency, it is more or less imperative to each party that he or she be able to control or influence the other's conduct. Thus, the power to control or influence another person resides in the control over the resources he or she values (Emerson, 1962).

\section{Supply and Demand of Cash Flow}

Government support is important for corporate development. Market entrants that receive government grants and loans via bank-issued shares or bonds can purchase plants, equipment, and raw materials and invest in projects. Further, because most SOEs are ultimately controlled by the government and because of their large firm size, high technology, and great background, their operating risk is lower and their chances of solvency higher. Therefore, they can access government assistance and loans more easily and attract further investment. The outcome of this is that SOEs attain adequate finance and are thus not prone to manipulating cash flow. Moreover, for social and political reasons (e.g., with regard to maintaining employment and social stability), the Chinese government at all levels has been reluctant to bankrupt SOEs (Zou and Xiao, 2006). This provides another reason why the government provides a steady flow of financial support to SOEs. Indeed, some SOEs are so important to the local economy that even if they make a loss, they can still afford to make huge investments in restructuring because of their vast levels of financial assistance from the government.

However, because small-sized non-SOEs face greater uncertainty and higher risk in the marketplace, banks are reluctant to lend them money and thus they face difficulties in attracting financial support. Ma and Parish (2006) suggest that Chinese private entrepreneurs made generous donations to government welfare projects until the 1990s, 
gaining in exchange political access and social status via appointments to political councils. Thus, by giving considerable charitable contributions, Chinese private entrepreneurs elicited social and political benefits in return.

Because resource dependence theory only focuses on the positive externalities of resource heterogeneity (i.e., creating the economic rent), but neglects negative externalities, opportunistic behavior may develop. Since corporate access to resources is based on certain factors and the context in which the organization is embedded (Pfeffer and Salancik, 2003), these factors control some of the organizational activities they regulate. Further, in Chinese listed companies, a mindset of the need to window dress their "shop fronts" to meet bank and other creditor requirements can develop during the process of gaining access to cash and other investments. With this outlook, some companies are prone to manipulate earnings management and/or cash flow in order to enhance performance.

Dichev and Skinner (2002) use a database of private corporate lending agreements to test the debt covenant hypothesis. Debt covenants are optimally set more tightly in private lending agreements than they are in public debt agreements (Smith and Warner, 1979), which implies that the covenants in private debt agreements are more likely to affect managers' financial reporting decisions. Moreover, the cost and benefits of avoiding covenant violations are likely to be substantially larger for managers of firms that are suffering financial difficulty. Once firm performance deteriorates, managers' abilities to avoid debt covenant constraints are likely to reduce. For example, if the company's economic performance is declining, managers must make greater and more aggressive accrual choices, thereby increasing reported earnings (especially when their accounting discretion has already been "used up"), while real choices are likely to be constrained by declining cash flow. Hence, managers may also choose to manipulate operating cash flow (e.g., EBIT, EBITDA) at the year end. Since debt-to-cash flow ratios are important indicators, sufficient cash flow shows repayment capability.

Billings and Morton (2002) also demonstrate the importance of operating cash flow for reducing credit risk. If a company's earnings per share is higher than that of other companies but its cash flow is smaller, then it will still draw the attention of analysts and investors. In this event, the company will face problems repaying its loans and find further difficulties obtaining new loans, as it is now classified as a credit risk. Further, because cash flow is by far the most efficient method for reflecting solvency, managers also need to maintain large amounts of cash flow into their companies.

Paradoxically, because SOEs know that they can obtain guaranteed funding from the government, SOE managers may purposely manipulate cash flow downward in order to show a deficit or poor profit and thus obtain more financial support from the government. By contrast, non-SOEs might deliberately manipulate cash flow upward even though their cash flow is poor. Since a cash surplus implies a position of solvency, lenders believe that they can repay the money.

The foregoing analysis implies that a healthy cash flow is paramount for obtaining loans, especially for non-SOEs because their need for cash and other funding from the government, banks, and other creditors is greater. By contrast, SOEs want to decrease cash flow in order to obtain more financial support from the government. In summary, from the perspective of resource dependence theory, we propose two directional hypotheses of cash flow manipulation:

H1a: Cash flow in non-SOEs is manipulated to appear higher than normal cash flow.

H1b: Cash flow in SOEs is manipulated to appear lower than normal cash flow.

\section{Manipulation Limitations/Constraints}

As discussed earlier, most listed firms in China are carve-outs or spin-offs from large SOEs. Shleifer and Vishny (1997) point out that the ownership of SOEs is controlled by corporate bureaucracy and that corporate bureaucracies are always appointed by the government. Therefore, the managers in SOEs often hold political positions in central and local governments. Under this constraint, they cannot manipulate cash flow to appear too low, since very bad cash flow performance would imply poor management capability and/or inefficient investment strategies, which would pose a threat to their positions. Displaying a very low cash flow could also make SOEs face 
financial risk, leading to a difficulty obtaining bank loans. On the contrary, non-SOEs manipulate cash flow upward without restrictions as they believe that signals their payment capability to lenders. We speculate that non-SOEs are more prone than SOEs to manipulate cash flow in order to enhance their cash flow performance. Based on the above discussion, we constructed a comprehensive theoretical framework to explain the determinants and motivation of cash flow manipulation for SOE and non-SOEs as shown in Figure 1. We also propose hypothesis H2:

H2: Cash flow manipulation is more prevalent in non-SOEs than it is in SOEs.

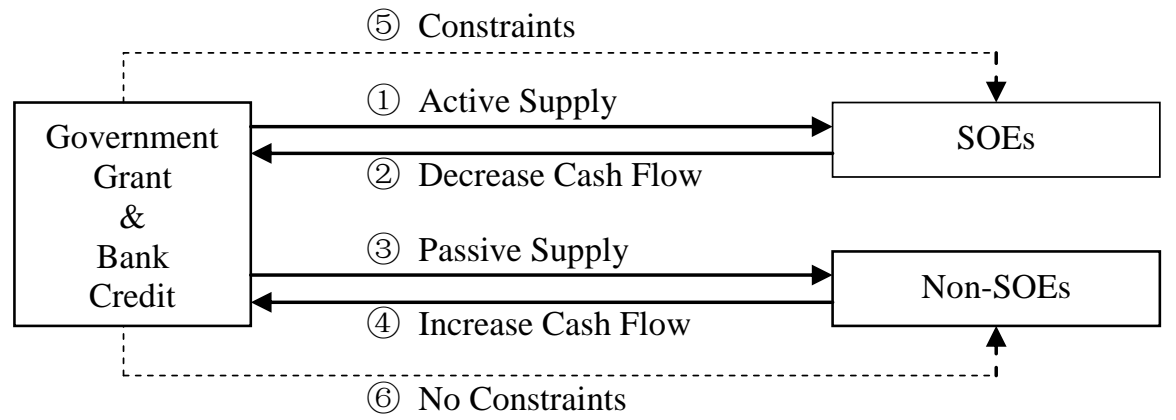

1. The government and banks actively support sufficient funding to SOEs.

2. The managers of SOEs manipulate cash flow to appear lower than normal in order to show cash flow shortages and thus obtain more government funding.

3. The government and banks are reluctant to supply funding to non-SOEs.

4. The managers of non-SOEs manipulate cash flow to appear higher than normal in order to show solvency and thus receive more government funding.

5. The managers of SOE cannot manipulate cash flow too low since poor cash flow performance would pose a threat to their political positions and banks may worry about the risk of non-repayment.

6. The managers of non-SOEs manipulate cash flow upward without restrictions.

Figure 1: Theoretical Framework of Cash Flow Manipulation Between SOEs and Non-SOEs

\section{RESEARCH DESIGN}

\section{Data and Sample}

Since 1999, the cash flow statements of listed companies have been required to be disclosed by the China Security Regulatory Commission. Thus, the data on listed companies used for the sample in this study came from 1999, namely a period when company cash flow was recognized to be more stable and precise. We selected our sample as follows. We began with an original sample of 14,441 firm-year observations, which listed only A-share stock market-listed firms that did not belong to either financial or insurance industries. We then removed from this initial number 487 observations whose gearing ratios were larger than 1 and 1703 observations whose listing histories were less than three years. The remaining 12,251 firm-year observations were used as the final research sample. All financial data were derived from the CSMAR database.

\section{Variables and Models}

\section{Variables}

In order to determine the level of cash flow manipulation, we must calculate the abnormal levels of operating cash flow $(C F O)$, since $C F O$ reflects cash inflow and outflow in all companies. According to Roychowdhury (2006), we also assume that normal cash flow has a linear relationship with sales; thus, abnormal operating cash flow $(A C F O)$ is defined as the deviation between reported cash flow $(R C F O)$ and real $C F O$. Reported cash flow is presented in the cash flow statement, whereas real $C F O$ is only estimated. 
The estimated model initially developed by Dechow, Kothari, and Watts (1998) was based on the selling process, while $\mathrm{Li}$, Guo, and Zhang (2009) improved the model by considering the effect of fixed costs on the estimation of CFO. In line with the model put forward by Li et al. (2009), we calculate real CFO as net operating cash flow based on the items in the direct method cash flow statement as follows:

Cash flows from operating activities $\left(C F O_{i t}\right)=$ Cash received from the sale of goods or rendering of services $\left(S C_{i t}\right)$ - Cash paid for goods and services $\left(P C_{i t}\right)+$ Net cash paid and received for taxes $\left(T C_{i t}\right)$ - Cash paid to employees $\left(E C_{i t}\right)+$ Other net cash relating to operating activities $\left(O C_{i t}\right)$

Then, the estimated operating cash flow estimation models are as follows:

$$
\begin{aligned}
C F O_{i t} / A_{i t-1} & =\alpha_{0}+\alpha_{1}\left(S_{i t} / A_{i t-1}\right)+\alpha_{2}\left(\Delta S_{i t} / A_{i t-1}\right)+\alpha_{3}\left(\Delta S_{i t-1} / A_{i t-1}\right)+\alpha_{4}\left(T C_{i t} / A_{i t-1}\right) \\
& +\alpha_{5}\left(E C_{i t} / A_{i t-1}\right)+\alpha_{6}\left(O C_{i t} / A_{i t-1}\right)+\varepsilon_{i t}
\end{aligned}
$$

where:

$C F O_{i t}$ is operating cash flow in year $t$;

$A_{i t-1}$ is total assets in year $t-1$;

$S_{i t}$ is sales in year $t$;

$\Delta S_{i t}$ is sales from year $t-1$ to $t$;

$\Delta S_{i t-1}$ is sales from year $t-2$ to $t-1$;

$T C_{i t}$ is net cash flow from receiving and paying taxes and expenses;

$E C_{i t}$ is net cash paid to employees; and

$O C_{i t}$ is net cash flow from receiving and paying other cash relating to operating activities.

According to the Jones (1991) model, we divide reported $C F O$ into estimated operating cash flow (ECFO) and $A C F O$ as follows:

$R C F O_{i t}=E C F O_{i t}+A C F O_{i t}$

We then acquire $A C F O$ as follows.

$A C F O_{i t}=R C F O_{i t}-E C F O_{i t}$

Because the largest shareholder in a listed company always determines ownership, we select the stock property of the primary shareholder from CSMAR as the determinant of whether the firm is an SOE, for which we use the variable state-controlled enterprise $(S C E)$ in this paper. $S C E$ thus takes the value of 1 if the firm's largest shareholder's property is state stock and it is a SOE, and 0 otherwise. This includes private enterprises as well as foreign-funded enterprises.

We also select the following control variables: shareholding concentration (SHC), company size (SIZE), leverage $(L E V)$, return on assets $(R O A)$, revenue growth ratio $(G R O W)$, whether the company has established an auditing committee or not, what auditing opinion was given, whether the company is audited by the Big $4 / 5$ accounting firms and the industry and year it belongs to. The definitions of these variables are listed in Table 1. 
Table 1: Variables and Definitions

\begin{tabular}{|l|l|}
\hline Variable & \multicolumn{1}{|c|}{ Definitions } \\
\hline$A A C F O$ & Absolute value of $A C F O$ \\
\hline$A C F O$ & Abnormal operating cash flow: $A C F O=R C F O-E C F O$ \\
\hline$A C F O_{1}$ & Abnormal operating cash flow (positive) \\
\hline$A C F O_{2}$ & Abnormal operating cash flow (negative) \\
\hline$S C E$ & $\begin{array}{l}\text { State-controlled enterprise: dummy variable coded 1 if the company's largest shareholder's property is state stock, 0 } \\
\text { otherwise }\end{array}$ \\
\hline$S H C$ & Shares owned by the largest shareholder/total share capital issued \\
\hline$S I Z E$ & Natural logarithm of total assets \\
\hline$L E V$ & Ratio of debt to total assets \\
\hline$R O A$ & Return on assets: net profits/assets \\
\hline$G R O W$ & Revenue growth ratio: revenue changes from last year to this year/ revenue this year \\
\hline$A U C O M$ & Dummy variable coded 1 if the company has established an audit committee, 0 otherwise \\
\hline$O P I N$ & Dummy variable coded 1 if the auditing opinion given by auditors was a standard unqualified opinion, 0 otherwise \\
\hline$B I G 4$ & Dummy variable coded 1 if audited by the Big 4/5 accounting firms* \\
\hline$I N D U$ & $\begin{array}{l}11 \text { dummy variables for } 12 \text { industries, taking the manufacturing industry as reference } 0,1 \text { if the firm is non- } \\
\text { manufacturing. }\end{array}$ \\
\hline$Y E A R$ & 10 dummy variables for 11 industries, coded 0 if the firm is in year 1999, coded 1 if the firm is in year 2000.... \\
\hline
\end{tabular}

* There were five big accounting firms before 2002 when the Enron scandal was exposed.

Regression Model

To compare the cash flow manipulation behavior of SOEs and non-SOEs, we construct the following Cash Flow and Ownership Model.

$$
\begin{aligned}
C F M_{i t} & =\beta_{0}+\beta_{1} S C E_{i t}+\beta_{2} S H C_{i t}+\beta_{3} S I Z E_{i t}+\beta_{4} L E V_{i t}+\beta_{5} R_{i t}+\beta_{6} G R O W_{i t}+\beta_{7} \text { OPIN }_{i t} \\
& +\beta_{8} B I G 4_{i t}+\sum_{\gamma=1}^{11} \beta_{\gamma+8} I N D U_{i t}+\sum_{\theta=1}^{10} \beta_{\theta+19} Y E A R_{i t}+\varepsilon_{i t}
\end{aligned}
$$

\section{EMPIRICAL ANALYSIS}

\section{Descriptive Statistics}

Table 2 presents the descriptive statistics of the variables introduced in Table 1. The minimum absolute value of abnormal $C F O(A A C F O)$ is rounded to 0.0000 while the reported cash flow figures deviate from the estimated values by an average of $7.15 \%$ with a maximum deviation of 3.0870 . Minimum abnormal $C F O(A C F O)$ is -1.4299 which means that estimated cash flow is higher than that reported. In other words, managers manipulate reported cash flow to appear lower than real cash flow. A total of $73 \%$ of sample companies are SOEs, while the average value of the shares owned by the largest shareholder is $18.71 \%$. The logarithm of the average size of the sample is 21.31. This means that the average total assets of sample companies are 4.264 billion RMB. Average leverage $(L E V)$ is $49.20 \%$, which implies that the average gearing ratio remains at a rational level. Average return on assets $(R O A)$ is $3.01 \%$, which shows that the profitability of sample companies is relatively low. However, the average revenue growth ratio is $21.71 \%$, which suggests rapid revenue growth. Further, fewer than one-third of the sample companies have established auditing committee. Finally, OPIN and BIG4 were 90.89\% and 6.28\%, respectively, which shows that most companies have been issued with a standard unqualified audit opinion but that fewer than one in 16 companies were audited by Big 4/5 accounting firms. 
Table 2: Descriptive Statistics

\begin{tabular}{|l|c|c|c|c|c|c|c|}
\hline \multicolumn{1}{|c|}{ Variable } & Minimum & Q1 & Mean & Media & Q3 & Maximum & Std. Dev. \\
\hline AACFO & 0.0000 & 0.0212 & 0.0715 & 0.0475 & 0.0909 & 3.0870 & 0.0910 \\
\hline ACFO & -1.4299 & -0.0471 & 0.0000 & -0.0011 & 0.0481 & 3.0870 & 0.1157 \\
\hline SCE & 0 & 0 & 0.7303 & 1 & 1 & 1 & 0.4438 \\
\hline SHC & 0.0000 & 0.0715 & 0.1871 & 0.1477 & 0.2757 & 0.7847 & 0.1446 \\
\hline SIZE & 14.9375 & 20.6039 & 21.3109 & 21.1903 & 21.8972 & 28.0031 & 1.0649 \\
\hline LEV & 0 & 0.3606 & 0.4920 & 0.4988 & 0.6268 & 1.0493 & 0.1871 \\
\hline ROA & -0.9986 & 0.0093 & 0.0301 & 0.0317 & 0.0605 & 2.3174 & 0.0798 \\
\hline GROW & -0.7283 & -0.0335 & 0.2171 & 0.1289 & 0.3205 & 3.7745 & 4.9851 \\
\hline AUCOM & 0 & 0 & 0.2023 & 0 & 0 & 1 & 0.4017 \\
\hline OPIN & 0 & 1 & 0.9089 & 1 & 1 & 1 & 0.2878 \\
\hline BIG4 & 0 & 0 & 0.0628 & 0 & 0 & 1 & 0.2426 \\
\hline
\end{tabular}

To compare the growth trend for sample companies, the numbers of SOEs and non-SOEs by sample year are displayed in Table 3. This table shows that the number of SOEs and non-SOEs increased at a similar rate, although the former was always twice the number of the latter.

Table 3: Breakdown of SOEs and Non-SOEs

\begin{tabular}{|c|c|c|c|c|c|c|c|c|c|c|c|c|}
\hline & 1999 & 2000 & 2001 & 2002 & 2003 & 2004 & 2005 & 2006 & 2007 & 2008 & 2009 & Total \\
\hline SOEs & 495 & 643 & 650 & 756 & 817 & 863 & 894 & 931 & 929 & 963 & 1,006 & 8947 \\
\hline \begin{tabular}{|l} 
Non-SOEs \\
\end{tabular} & 208 & 243 & 235 & 262 & 271 & 279 & 282 & 325 & 334 & 376 & 489 & 3304 \\
\hline
\end{tabular}

\section{Correlation Analyses}

Table 4 lists the correlation matrix of the main variables used in the regression model (5). The absolute value of abnormal CFO $(A A C F O)$ has a significantly negative correlation with $S C E$ but a significantly positive correlation with shareholding concentration $(S H C)$, company size, leverage $(L E V)$, firm performance, and growth. Further, from the correlation coefficients among these variables, it can be seen that there is no serious multicollinearity problem.

Table 4: Correlation Matrix of $A A C F O$ and $S C E$

\begin{tabular}{|c|c|c|c|c|c|c|c|c|c|c|}
\hline & $A A C F O$ & $S C E$ & SHC & SIZE & $L E V$ & $R O A$ & GROW & $A U C O M$ & OPIN & BIG4 \\
\hline$A A C F O$ & 1 & $-0.039 * *$ & $0.023 * *$ & $0.037 * *$ & 0.014 & $0.177 * *$ & $0.091 * *$ & $-0.017^{*}$ & $0.053 * *$ & $0.037 * *$ \\
\hline$S C E$ & $-0.033 * *$ & 1 & $0.30 * *$ & $0.165 * *$ & 0.013 & -0.016 & $0.036 * *$ & 0.011 & $0.074 * *$ & $0.057 * *$ \\
\hline SHC & $0.038 * *$ & $0.274 * *$ & 1 & $0.164 * *$ & $-0.105 * *$ & $0.140 * *$ & $0.073 * *$ & $-0.071 * *$ & $0.066 * *$ & $0.099 * *$ \\
\hline SIZE & $0.056 * *$ & $0.169 * *$ & $0.200 * *$ & 1 & $0.215 * *$ & $0.157 * *$ & $0.144 * *$ & $0.098 * *$ & $0.154 * *$ & $0.250 * *$ \\
\hline$L E V$ & $0.057 * *$ & 0.008 & $-0.107 * *$ & $0.192 * *$ & 1 & $-0.355 * *$ & $0.053 * *$ & $0.042 * *$ & $-0.169 * *$ & $-0.041 * *$ \\
\hline ROA & $0.148 * *$ & 0.011 & $0.123 * *$ & $0.155^{* *}$ & $-0.315 * *$ & 1 & $0.341 * *$ & 0.010 & $0.282 * *$ & $0.095 * *$ \\
\hline GROW & $0.053 * *$ & -0.009 & & & 0.019 & 0.020 & 1 & -0.001 & $0.171 * *$ & 0.020 \\
\hline AUCOM & -0.022 & 0.011 & $-0.071 * *$ & $0.092 * *$ & $0.044 * *$ & 0.004 & -0.006 & 1 & $0.063 * *$ & -0.003 \\
\hline OPIN & $0.035 * *$ & $0.074 * *$ & $0.067 * *$ & $0.161 * *$ & $-0.1889 * *$ & $0.319 * *$ & 0.002 & & 1 & $0.040 * *$ \\
\hline BIG4 & 0.019 & $0.057 * *$ & $0.099 * *$ & $0.324 * *$ & $-0.042 * *$ & $0.068 * *$ & -0.005 & & 0.040 & 1 \\
\hline
\end{tabular}

Notes:

(1) The upper right-hand triangle is Spearman's rank correlation coefficient and the bottom left-hand triangle is Pearson's correlation coefficient.

(2) $* *$ and $*$ indicate significance at the $1 \%$ and $5 \%$ levels, respectively.

We next carry out a further correlation analysis between positive abnormal cash flow manipulation $\left(A C F O_{1}\right) /$ negative abnormal cash flow manipulation $\left(A C F O_{2}\right)$ and the other main variables to ascertain the degree of cash flow manipulation in SOEs and non-SOEs. The correlation results listed in Tables 5 and 6 again show that there is no serious multicollinearity problem. 
Table 5: Correlation Matrix of $A C F O_{1}$ and $S C E$

\begin{tabular}{|c|c|c|c|c|c|c|c|c|c|c|}
\hline & $A C F O_{1}$ & $S C E$ & SHC & SIZE & $L E V$ & $R O A$ & GROW & $A U C O M$ & OPIN & BIG4 \\
\hline$A C F O_{1}$ & 1 & $-0.037 * *$ & $0.047 * *$ & $0.069 * *$ & $-0.051 * *$ & $0.320 * *$ & $0.157 * *$ & 0.032 & $0.082 * *$ & $0.064 * *$ \\
\hline$S C E$ & $-0.025^{*}$ & 1 & $0.324 * *$ & $0.177 * *$ & 0.014 & -0.023 & 0.010 & 0.016 & $0.066 * *$ & $0.047 * *$ \\
\hline SHC & $0.050 * *$ & $0.295 * *$ & 1 & $0.186^{* *}$ & $-0.141^{* *}$ & $0.155^{* *}$ & $0.058 * *$ & $-0.070 * *$ & $0.069 * *$ & $0.119 * *$ \\
\hline SIZE & $0.057 * *$ & $0.178 * *$ & $0.230 * *$ & 1 & $0.230 * *$ & $0.107 * *$ & $0.122 * *$ & $0.089 * *$ & $0.115^{* *}$ & $0.292 * *$ \\
\hline LEV & 0.021 & 0.010 & $-0.134 * *$ & $0.215^{* *}$ & 1 & $-0.399 * *$ & $0.106 * *$ & $0.057 * *$ & $-0.107 * *$ & $-0.050 * *$ \\
\hline$R O A$ & $0.247 * *$ & -0.004 & $0.118 * *$ & $0.075 * *$ & $-0.293 * *$ & 1 & $0.291 * *$ & 0.009 & $0.214 * *$ & $0.093 * *$ \\
\hline GROW & $0.048 * *$ & -0.026 & 0.005 & -0.006 & 0.008 & 0.028 & 1 & -0.008 & $0.124 * *$ & -0.001 \\
\hline$A U C O M$ & $0.043 * *$ & 0.016 & $-0.069 * *$ & $0.094 * *$ & $0.056 * *$ & 0.002 & 0.022 & 1 & $0.044 * *$ & 0.001 \\
\hline OPIN & $0.042 * *$ & $0.066^{* *}$ & $0.066^{* *}$ & $0.126 * *$ & $-0.122 * *$ & $0.198 * *$ & 0.006 & $0.044 * *$ & 1 & 0.020 \\
\hline BIG4 & 0.028 & $0.047 * *$ & $0.123 * *$ & $0.372 * *$ & $-0.045^{* *}$ & $0.058 * *$ & -0.007 & 0.001 & 0.020 & 1 \\
\hline
\end{tabular}

Notes:

(1) The upper right-hand triangle is Spearman's rank correlation coefficient and the bottom left-hand triangle is Pearson's correlation coefficient.

(2) ** and * indicate significance at the $1 \%$ and $5 \%$ levels, respectively.

Table 6: Correlation Matrix of $\mathrm{ACFO}_{2}$ and $\mathrm{SCE}$

\begin{tabular}{|c|c|c|c|c|c|c|c|c|c|c|}
\hline & $\mathrm{ACFO}_{2}$ & $S C E$ & SHC & SIZE & $L E V$ & ROA & GROW & AUCOM & OPIN & BIG4 \\
\hline $\mathrm{ACFO}_{2}$ & 1 & $0.042 * *$ & 0.002 & -0.0045 & $-0.080 * *$ & $-0.040 * *$ & -0.024 & $-0.055^{* *}$ & -0.030 & -0.002 \\
\hline$S C E$ & $0.041 * *$ & 1 & $0.274 * *$ & $0.150 * *$ & 0.015 & -0.018 & $0.055 * *$ & 0.008 & $0.076^{* *}$ & $0.066^{* *}$ \\
\hline SHC & $-0.025 *$ & $0.252 * *$ & 1 & $0.136 * *$ & $-0.063 * *$ & $0.113 * *$ & $0.081 * *$ & $-0.071 * *$ & $0.058 * *$ & $0.070 * *$ \\
\hline SIZE & $-0.053 * *$ & $0.154 * *$ & $0.155 * *$ & 1 & $0.222 * *$ & $0.165 * *$ & $0.142 * *$ & $0.099 * *$ & $0.167 * *$ & $0.196 * *$ \\
\hline$L E V$ & $-0.097 * *$ & 0.011 & $-0.072 * *$ & & 1 & $-0.302 * *$ & 0.024 & 0.028 & $-0.206^{* *}$ & -0.021 \\
\hline ROA & $-0.052 * *$ & 0.015 & $0.113 * *$ & $0.190 * *$ & $-0.314 * *$ & 1 & $0.357 * *$ & & & $0.078 * *$ \\
\hline GROW & $-0.064 * *$ & -0.004 & 0.018 & -0.001 & 0.025 & 0.023 & 4 & 0.001 & $0.192 * *$ & 0.029 \\
\hline$A U C O M$ & $-0.058 * *$ & 0.008 & $-0.074 * *$ & $0.110 * *$ & 0.026 & 0.026 & -0.008 & 1 & $0.082 * *$ & -0.006 \\
\hline OPIN & -0.030 & $0.076 * *$ & $0.061 * *$ & $0.175^{* *}$ & $-0.227 * *$ & $0.387 *$ & & $0.082 * *$ & 1 & $0.0489 * *$ \\
\hline BIG4 & -0.006 & $0.066 * *$ & $0.0623 * *$ & $0.251 * *$ & -0.028 & $0.057 * *$ & -0.004 & -0.006 & $0.049 * *$ & 1 \\
\hline
\end{tabular}

Notes:

(1) The upper right-hand triangle is Spearman's rank correlation coefficient and the bottom left-hand triangle is Pearson's correlation coefficient.

(2) ** and * indicate significance at the $1 \%$ and $5 \%$ levels, respectively.

\section{T-test Analysis}

We next compare the main variables by T-test. Table 7 shows that positive abnormal $\mathrm{CFO}\left(A C F O_{I}\right)$ in nonSOEs is significantly higher than that in SOEs. This finding means that the cash flow reported by non-SOEs is higher than normal. However, the absolute value of negative abnormal CFO $\left(A C F O_{2}\right)$ in non-SOEs is significantly higher than in SOEs, which implies that the cash flow reported by SOEs is lower than normal. Thus, H1a and H1b are supported. Further, the absolute value of abnormal CFO (AACFO) in non-SOEs (0.0764) is higher than that in SOEs (0.0696) at a $1 \%$ significance level. This finding means that the prevalence of cash flow manipulation by nonSOEs is greater than that by SOEs. Thus, $\mathrm{H} 2$ is supported.

Table 7: T-test Results for SOEs and Non-SOEs

\begin{tabular}{|c|c|c|c|c|c|c|}
\hline Variables & SCE & Number & Mean & Std. Dev. & Mean Diff. & t-value \\
\hline \multirow{2}{*}{$A C F O_{1}$} & 0 & 1556 & 0.0755 & 0.0860 & \multirow{2}{*}{$0.0054 * *$} & \multirow{2}{*}{2.0780} \\
\hline & 1 & 4488 & 0.0710 & 0.0962 & & \\
\hline \multirow{2}{*}{$\mathrm{ACFO}_{2}$} & 0 & 1748 & -0.0762 & 0.0965 & \multirow{2}{*}{$-0.0080 * * *$} & \multirow{2}{*}{-3.0397} \\
\hline & 1 & 4459 & -0.0682 & 0.0845 & & \\
\hline \multirow{2}{*}{$A A C F O$} & 0 & 3304 & 0.0764 & 0.0917 & \multirow{2}{*}{$0.0067 * * *$} & \multirow{2}{*}{3.6027} \\
\hline & 1 & 8947 & 0.0696 & 0.0906 & & \\
\hline \multirow{2}{*}{ SHC } & 0 & 3304 & 0.1218 & 0.0588 & \multirow{2}{*}{$0.0893 * * *$} & \multirow{2}{*}{-36.1887} \\
\hline & 1 & 8947 & 0.2111 & 0.0743 & & \\
\hline
\end{tabular}

C 2013 The Clute Institute http://www.cluteinstitute.com/ 


\begin{tabular}{|c|c|c|c|c|c|c|}
\hline \multirow{2}{*}{$S I Z E$} & 0 & 3304 & 21.0149 & 0.9711 & \multirow{2}{*}{$-0.4052 * * *$} & \multirow{2}{*}{19.8896} \\
\hline & 1 & 8947 & 21.4202 & 1.0772 & & \\
\hline \multirow{2}{*}{$L E V$} & 0 & 3304 & 0.4893 & 0.0557 & \multirow{2}{*}{-0.0336} & \multirow{2}{*}{-0.9488} \\
\hline & 1 & 8947 & 0.4930 & 0.0541 & & \\
\hline \multirow{2}{*}{$R O A$} & 0 & 3304 & 0.0286 & 0.0871 & \multirow{2}{*}{-0.0021} & \multirow{2}{*}{-1.2071} \\
\hline & 1 & 8947 & 0.0307 & 0.0769 & & \\
\hline \multirow{2}{*}{ GROW } & 0 & 3304 & 1.6171 & 0.0466 & \multirow{2}{*}{-0.8682} & \multirow{2}{*}{-1.0049} \\
\hline & 1 & 8947 & 0.7489 & 0.0753 & & \\
\hline \multirow{2}{*}{$A U C O M$} & 0 & 3304 & 0.1946 & 0.3959 & \multirow{2}{*}{$-0.0106 *$} & \multirow{2}{*}{-1.9074} \\
\hline & 1 & 8947 & 0.2052 & 0.4039 & & \\
\hline \multirow{2}{*}{ OPIN } & 0 & 3304 & 0.8738 & 0.3321 & \multirow{2}{*}{$-0.0481 * * *$} & \multirow{2}{*}{-7.4695} \\
\hline & 1 & 8947 & 0.9219 & 0.2684 & & \\
\hline \multirow{2}{*}{$B I G 4$} & 0 & 3304 & 0.0399 & 0.0791 & \multirow{2}{*}{$-0.0312 * * *$} & \multirow{2}{*}{-7.1674} \\
\hline & 1 & 8947 & 0.0711 & 0.0876 & & \\
\hline
\end{tabular}

Notes: $* * *, * *$, and $*$ indicate that the correlation is significant at the levels of $1 \%, 5 \%$, and $10 \%$, respectively.

\section{Regression Results}

Table 8 presents the regression results of $S C E$ on $A C F O_{1}, A C F O_{2}$, and $A A C F O$. The coefficient of $S C E$ on $A C F O_{1}$ is significantly negative (coefficient $=-0.0065, t=2.2782$ ), indicating that reported cash flow is higher than normal when $S C E=0$. This finding illustrates that compared with SOEs, non-SOEs are prone to manipulate their cash flow statements upward. Therefore, H1a is supported. The coefficient of $S C E$ on $A C F O_{2}$ is significantly negative (coefficient $=0.0074, t=2.8943$ ), indicating that reported cash flow is lower than normal when $S C E=1$. Therefore, compared with non-SOEs, SOEs are prone to manipulate their cash flow statements downward. Thus, $\mathrm{H} 1 \mathrm{~b}$ is supported. The coefficient of $S C E$ on $A A C F O$ is significantly negative (coefficient $=-0.0072, t=3.7578$ ), indicating that the degree of cash flow manipulation is deeper when $S C E=0$. This regression result demonstrates that non-SOEs are more prone to manipulating cash flow compared with SOEs. Thus, H2 is supported.

Table 8: Regression Results for Cash Flow Manipulation by SOEs and Non-SOEs

\begin{tabular}{|c|c|c|c|}
\hline & $A C F O_{1}$ & $\mathrm{ACFO}_{2}$ & $A A C F O$ \\
\hline Constant & $0.0639 * *$ & $-0.0683 * * *$ & $0.0794 * * *$ \\
\hline$S C E$ & $-0.0065^{* *}$ & $0.0074 * * *$ & $-0.0072 * * *$ \\
\hline$S H C$ & 0.0316 *** & $-0.0379 * * *$ & $0.0355 * * *$ \\
\hline SIZE & -0.0018 & 0.0020 & $-0.0023 * *$ \\
\hline$L E V$ & $0.0506 * * *$ & $-0.0489 * * *$ & $0.0510 * * *$ \\
\hline$R O A$ & 0.3180 *** & $-0.0673 * * *$ & $0.1939 * * *$ \\
\hline GROW & $0.0002 * * *$ & $-0.0001 * * *$ & $0.0001 * * *$ \\
\hline OPIN & -0.0009 & -0.0042 & -0.0022 \\
\hline BIG4 & $0.0089 *$ & 0.0011 & $0.0062 *$ \\
\hline$I N D U$ & \multicolumn{3}{|c|}{ Controlled } \\
\hline$Y E A R$ & \multicolumn{3}{|c|}{ Controlled } \\
\hline$N$ & 12251 & 6044 & 6207 \\
\hline $\operatorname{adj.} R^{2}$ & 0.0802 & 0.0994 & 0.0848 \\
\hline
\end{tabular}

Notes: $* * * * *$, and $*$ indicate that the correlation is significant at the levels of $1 \%, 5 \%$, and $10 \%$, respectively.

\section{CONCLUSION}

This paper explored whether SOEs and non-SOEs in China have different attitudes toward cash flow manipulation. Using a sample of 12,251 firm-year observations based on companies listed on the Chinese stock market from 1999 to 2009, it was discovered that 1) non-SOEs are prone to manipulate cash flow upward, 2) SOEs are prone to manipulate cash flow downward, and 3) the degree of cash flow manipulation is deeper in non-SOEs than it is in SOEs. 
These results imply different attitudes toward cash flow manipulations for SOEs and non-SOEs. Therefore, cash flow manipulation should be reduced or settled according to a company's status as state-owned or otherwise. First, relaxing the policy of lending to non-SOEs may provide this group of firms with financial support and thereby reduce cash flow manipulating behavior. Second, tightening the policy of lending to SOEs may enhance their risk management approaches and thereby prevent them from falsely lowering their cash flow statements in order to obtain money from the government. Third, the government should distribute funding in a more balanced way between SOEs and non-SOEs to provide an impetus for non-SOEs to develop in the capital market.

\section{ACKNOWLEDGEMENTS}

This research was partially supported by the National Social Science Foundation of China (No. 11CGL062), Humanity and Social Science Youth Foundation of Ministry of Education of China (No. 10YJC630225), National Science Foundation of China (No. 71172186), and New Century Educational Talents Plan of Education Ministry of PRC (No. NCET-07-0309). The Fundamental Research Funds for the Central Universities of China (2012jdhz17)

\section{AUTHOR INFORMATION}

Dr. Huiting Guo is an assistant professor in School of Economics and Management, Chang'an University. She got her PhD degree in the School of Management at Xi'an Jiaotong University this July. Her main research interests include corporate governance and financial disclosure. E-mail: guohuiting@gmail.com

Dr. Fangjun Wang is an associate professor of accounting in the School of Management at Xi'an Jiaotong University. His main research interests include corporate governance and corporate social responsibility, and he is currently directing the research project (No. 11CGL062) funded by National Social Science Foundation of China, and the research project of the Humanity and Social Science Youth Foundation of Ministry of Education of China (No. 10YJC630225). E-mail: wangfangjun@ mail.xjtu.edu.cn (Corresponding author)

Dr. Junrui Zhang is a professor of accounting in the School of Management at Xi'an Jiaotong University. His main research interests include corporate governance, accounting restatements, and earnings management, and he is currently leading the research project (No. 71172186) funded by National Natural Science Foundation of China, and the project funded by New Century Educational Talents Plan Of Education Ministry of PRC (No. NCET-07-0309). E-mail: zhangjr@mail.xjtu.edu.cn

\section{REFERENCES}

1. Abdel-Khalik, A. R., Wong, K. A. \& Wu A. (1999). The information environment of China's A and B shares: Can we make sense of the numbers? The International Journal of Accounting, 34(4): 467-489.

2. Aboody, D. \& Kasznik, R. (2000). CEO stock option awards and the timing of corporate voluntary disclosures. Journal of Accounting and Economics, 29(1): 73-100.

3. Aharony, J., Lee, C. W. J. \& Wong, T. J. (2000). Financial packaging of IPO firms in China. Journal of Accounting Research, 38(1): 103-126.

4. Billings, B. K. \& Morton, R. M. (2002). The relation between SFAS No. 95 cash flows from operations and credit risk. Journal of Business Finance and Accounting, 29(5-6): 787-805.

5. Chen L. (2006). Listed companies manipulation over operational cash flow: An empirical study. Finance \& Economics, 4: 30-36.

6. Dechow, P. M. (1994). Accounting earnings and cash flows as measures of firm performance: The role of accounting accruals. Journal of Accounting and Economics, 18(1): 3-42.

7. Dechow, P., Kothari, S. \& Watts, R. (1998). The relation between earnings and cash flow. Journal of Accounting and Economics, 25(2): 133-168.

8. Dichev, I. D. \& Skinner, D. J. (2002). Large-sample evidence on the debt covenant hypothesis. Journal of Accounting Research, 40(4): 1091-1123.

9. Dittmar, A., Mahrt-Smith, J. \& Servaes, H. (2003). International corporate governance and corporate cash holdings. Journal of Financial and Quantitative Analysis, 38(1): 111-133.

10. Edmonds, C. T., Edmonds, J. E. \& Maher, J. J. (2011). The impact of meeting or beating analysts' operating cash flow forecasts on a firm's cost of debt. Advances in Accounting. 27(2): 242-255. 
11. Emerson, R. M. (1962). Power-dependence relations. American Sociological Review, 27(1): 31-41.

12. Fang, J. X. (2005). Market change and cash flow manipulation: Evidence from Chinese stock market. China Accounting Review, 2(1): 381-404.

13. Frankel, R. (2005). Managing reported operating cash flow: An empirical investigation of fourth quarter working capital decreases and benchmark beating. Working paper, MIT.

14. Guo, H. T., Zhang, J. R. \& Dong, N. Y. (2007). Cash flow manipulation in management buy-outs (MBO): Evidence from China listed companies. Accountant, 9: 4-9.

15. Guo, H. T., Zhang, J. R. \& Li, B. (2011). Research on motivation selection of cash flow manipulation in Chinese listed companies. Management Science, 5: 89-98.

16. Haw, I. M., Qi, D. \& Wu, W. (2001). The nature of information in accruals and cash flows in an emerging capital market: The case of China. The International Journal of Accounting, 36(4): 391-406.

17. Hewitt, M. (2009). Improving investors' forecast accuracy when operating cash flows and accruals are differentially persistent. The Accounting Review, 84(6): 1913-1931.

18. Jones, J. J. (1991). Earnings management during import relief investigations. Journal of Accounting Research, 29(2): 193-228.

19. Li, B., Guo, H. T. \& Zhang, J. R. (2009). The relationship between accounting flexibility and earnings management through real activities. Management Review, 21(6): 99-107.

20. Liu, Q. \& Lu, Z. J. (2007). Corporate governance and earnings management in the Chinese listed companies: A tunneling perspective. Journal of Corporate Finance, 13(5): 881-906.

21. Ma, D. \& Parish, W. L. (2006). Tocquevillian moments: Charitable contributions by Chinese private entrepreneurs. Social Forces, 85(2): 943-964.

22. Nwaeze, E. T., Yang, S. M. \& Yin Q. J. (2006). Accounting information and CEO compensation: The role of cash flow from operations in the presence of earning. Contemporary Accounting Research, 23(1): 227265.

23. Pfeffer, J. \& Salancik, G. R. (2003). The external control of organizations: A resource dependence perspective. Stanford Business Books, Stanford University Press.

24. Qian, Y. Y., Roland, G. \& Xu, C. G. (1999). Why is China different from Eastern Europe? Perspectives from organization theory. European Economic Review, 43(4-6): 1085-1094.

25. Roychowdhury, S. (2006). Earnings management through real activities manipulation. Journal of Accounting and Economics, 42(3): 335-370.

26. Smith, C. W. \& Warner, J. B. (1979). On financial contracting: An analysis of bond covenants. Journal of Financial Economics, 7(2): 117-161.

27. Shleifer, A. \& Vishny, R. W. (1997). A survey of corporation governance. Journal of Finance, 52(2): 737783.

28. Sun, Q. \& Tong, W. H. S. (2003). China share issue privatization: The extent of its success. Journal of Financial Economics, 70(2), 183-222.

29. Waldron, M. A., \& Jordan, C. E. (2010). The comparative predictive abilities of accrual earnings and cash flows in periods of economic turbulence: The case of the IT bubble. Journal of Applied Business Research, 26(1): 85-97.

30. Wang X. (2004a). Case study on cash flow monopoly methods. China Chartered Accountant, 7: 37-38.

31. Wang X. (2004b). On cash flow monopoly in Chinese listed companies. Security Market Herald, 5: 34-42.

32. Zhang R. (2007). Cash flow management in the Chinese stock market_— comparing with cash flow management in the US market. China Accounting Review, 5(3): 381-400.

33. Zhang, J. R., Dong, N. Y., \& Guo, H. T. (2007). From earnings management to cash flow manipulation- A new tendency under the integrating background of accrual-based accounting and cash - based accounting. Journal of Shanxi Finance and Economics University, 29(11): 114-118.

34. Zhang, J. R., Guo, H. T. \& Wang W. (2008). Cash flow manipulation over seasoned equity offerings (SEOs) E Evidence from China's A-share market. Journal of Shanxi Finance and Economics University, 30(10): 119-124.

35. Zhang, J. R., Guo, H. T., \& Xu, P. (2010). Study on Chinese listed companies' operating cash flow manipulation - based on companies in equipment \& manufacturing and wholesale $\&$ retail industries. Journal of Shanxi Finance and Economics University, 4: 106-113.

36. Zou, H. \& Xiao, J. Z. (2006). The financing behaviour of listed Chinese firms. The British Accounting Review, 38(3): 239-258. 